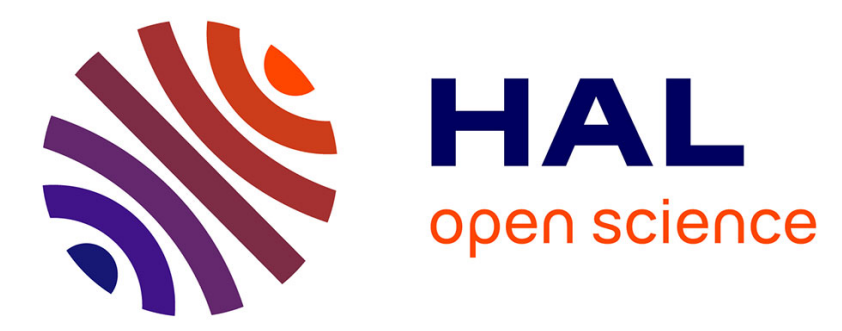

\title{
Changes in rearing conditions rapidly modify gut microbiota structure in Tenebrio molitor larvae
}

Marine C. Cambon, Jean-Claude Ogier, Anne Lanois-Nouri, Jean-Baptiste

Ferdy, Sophie Gaudriault

\section{- To cite this version:}

Marine C. Cambon, Jean-Claude Ogier, Anne Lanois-Nouri, Jean-Baptiste Ferdy, Sophie Gaudriault. Changes in rearing conditions rapidly modify gut microbiota structure in Tenebrio molitor larvae. 2018. hal-02788810

\author{
HAL Id: hal-02788810 \\ https://hal.inrae.fr/hal-02788810
}

Preprint submitted on 5 Jun 2020

HAL is a multi-disciplinary open access archive for the deposit and dissemination of scientific research documents, whether they are published or not. The documents may come from teaching and research institutions in France or abroad, or from public or private research centers.
L'archive ouverte pluridisciplinaire HAL, est destinée au dépôt et à la diffusion de documents scientifiques de niveau recherche, publiés ou non, émanant des établissements d'enseignement et de recherche français ou étrangers, des laboratoires publics ou privés.

\section{(c)(1)}

Distributed under a Creative Commons Attribution| 4.0 International License 


\section{Changes in rearing conditions rapidly modify gut microbiota}

\section{2 structure in Tenebrio molitor larvae}

3 Marine Cambon ${ }^{1,2}$, Jean-Claude Ogier $^{2}$, Anne Lanois ${ }^{2}$, Jean-Baptiste Ferdy ${ }^{1}$ and Sophie

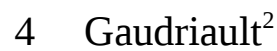

51 Laboratoire Evolution et Diversité Biologique, CNRS-Université Paul Sabatier, Toulouse, 6 France.

72 Laboratoire Diversité, Génome et Interaction Microorganisme Insectes, INRA-Université de 8 Montpellier, Montpellier, France.

12 Running title: Gut microbiota structure in T. molitor 
bioRxiv preprint first posted online Sep. 21, 2018; doi: http://dx.doi.org/10.1101/423178. The copyright holder for this preprint

(which was not peer-reviewed) is the author/funder, who has granted bioRxiv a license to display the preprint in perpetuity.

All rights reserved. No reuse allowed without permission.

14 The gut microbiota of multicellular organisms has been shown to play a key role in their host

15 biology. In mammals, it has an invariant component, responsible for establishing a mutualistic

16 relationship with the host. It also contains a dynamic fraction which facilitates adaptation in

17 response to changes in the environment. These features have been well described in mammals, but

18 little is known about microbiota stability or plasticity in insects. We assessed changes in microbiota

19 composition and structure in a reared insect after a change in rearing conditions. We reared

20 Tenebrio molitor (Coleoptera, Tenebrioninae) larvae for five days in soil samples from two river

21 banks and analyzed their gut microbial communities by a metabarcoding technique, using the V3-

22 V4 region of the 16S rRNA gene and the housekeeping gene gyrB. We found that soil-reared insects

23 had a significantly more diverse microbiota than the control insects and that insects reared in soil

24 from different sites had significantly different microbiota. We confirmed this trend by absolute

25 quantification of the two mains fluctuating taxonomic groups: the Enterobacteriaceae family and

26 the Pseudomonas genus, dominant in the soil-reared insects and in the control insects, respectively.

27 Our results suggest the existence of a resident microbiota in T. molitor gut, but indicate that rearing

28 changes can induce rapid and profound changes in the relative abundance of some of the members

29 of this resident microbiota.

30 Keywords: resident microbiota, T. molitor, soil acclimatization, microbiota plasticity

\section{Background}

32 Microorganisms have repeatedly been shown to play a key role in plant and animal biology

33 (Bordenstein and Theis 2015). If we are to understand the biology of a pluricellular organism, we

34 must consider its microbiota, the cohort of microorganisms associated with the host. In animals, the 
bioRxiv preprint first posted online Sep. 21, 2018; doi: http://dx.doi.org/10.1101/423178. The copyright holder for this preprint

(which was not peer-reviewed) is the author/funder, who has granted bioRxiv a license to display the preprint in perpetuity.

All rights reserved. No reuse allowed without permission.

35 gut microbiota is a key component, with major effects on host physiology. For example, the mammalian gut microbiota has been the object of many studies on digestive functions with health implications (Belizário and Napolitano 2015).

38 The composition of the mammalian gut microbiota displays both plasticity and invariant features.

39 The core microbiota, which consists of the microorganisms common to the majority of individuals

40 within a population, is generally defined as the most prevalent of the microbial species detected

41 (Shetty et al. 2017). This common fraction of the microbiota plays a fundamental role in supporting

42 the mutualistic symbiotic relationship with the host (Candela et al. 2012). For example, changes in

43 the human core microbiota are associated with physiological perturbations, such as obesity and

44 Crohn's disease (Turnbaugh et al. 2009; Hedin et al. 2015). However, another key feature of the

45 mammalian gut microbiota is its plasticity, i.e. its ability to change in composition and structure. In

46 humans, dietary changes induce a remarkable degree of variation in gut microbiota in terms of both

47 phylogenetic and functional composition (Candela et al. 2012). These changes depend on various

48 factors including host age, sex, genetic make-up, immune and health status (Shetty et al. 2017), but

49 also exposure to environmental bacteria, geographic origin and climate (Candela et al. 2012). It has

50 been suggested that this plasticity of the human gut microbiota facilitates rapid responses to

51 environmental change, resulting in rapid ecological adaptation (Alberdi et al. 2016).

52 Most studies on the gut microbiota concern mammals. However, the use of mammals, and more

53 generally of vertebrates, in experimental approaches raises numerous practical, financial and ethical

54 issues. Large-scale experiments require model organisms that are easy to manipulate and can be

55 obtained in large numbers. Insects are interesting experimental models in this respect. Although

56 their guts contain fewer microbial species than those of mammals (Engel and Moran 2013), insects

57 also rely on their gut microbiota for diverse functions, including development, nutrition, the

58 modulation of immune responses, gut homeostasis, protection from pathogens and toxins (Engel

59 and Moran 2013; Shi et al. 2013; Broderick et al. 2014; Erkosar and Leulier 2014; Caccia et al. 
bioRxiv preprint first posted online Sep. 21, 2018; doi: http://dx.doi.org/10.1101/423178. The copyright holder for this preprint

(which was not peer-reviewed) is the author/funder, who has granted bioRxiv a license to display the preprint in perpetuity.

All rights reserved. No reuse allowed without permission.

60 2016; Welte et al. 2016; Shao et al. 2017; Raymann and Moran 2018). The gut microbiota of non-

61 social insects is principally acquired from the environment through feeding (Engel and Moran

62 2013). Its composition depends on environmental conditions and diet in both laboratory and wild

63 individuals (Chandler et al. 2011; Montagna et al. 2015; Staudacher et al. 2016). For example, it has

64 been shown for some coleopteran species that microbiota changes with geographical location,

65 environmental condition, and life stage (Huang and Zhang 2013; Montagna et al. 2014).

66 One potential limit of these previous studies is that they used either insects from the wild, which

67 cannot be controlled for many of their characteristics, or lab-reared insects, which are controlled but

68 have a poorly diversified microbiota. Here we used laboratory-reared T. molitor larvae and

69 mimicked a soil environment by rearing the larvae for five days in different soil samples. We

70 assessed the changes in gut microbiota composition after acclimatization to soil samples and

71 demonstrated a large shift in gut microbial structure. We showed in addition that different soil

72 samples induced different modifications in insect microbiota, and that the observed plasticity was

73 probably dependent on changes in the abundance of some of the resident OTUs.

\section{Methods}

\section{Soil samples}

76 We sampled soil from riverside land around Montpellier in the South of France (Figure 1A): on the

77 banks of the Hérault river near Causse-De-La-Selle (N4349.884' E00341.222'; CDS sample) and

78 on those of the Lez river near Montferrier-sur-Lez (N4340.801' E00351.835'; MTF sample). Both

79 soils had a sand-silt-clay composition typical of riversides on chalky substrata. The sand:silt ratio

80 was higher for MFT than for CDS. We collected three soil subsamples from each plot. These

81 subsamples were taken at a depth of $20 \mathrm{~cm}$ and were separated by a distance of $10 \mathrm{~m}$. They were

82 named CDS1, CDS2, CDS3 and MTF1, MTF2, MTF3 (Figure 1B). The use of these six soil 
bioRxiv preprint first posted online Sep. 21, 2018; doi: http://dx.doi.org/10.1101/423178. The copyright holder for this preprint

(which was not peer-reviewed) is the author/funder, who has granted bioRxiv a license to display the preprint in perpetuity.

All rights reserved. No reuse allowed without permission.

83 subsamples made it possible to compare the variability in microbiota composition both between and

84 within plots. Each soil subsample was split into four portions, each of which was placed in a $1 \mathrm{~L}$

85 plastic box (Figure 1C), in which it was mixed with heat-sterilized (20 min at $121^{\circ} \mathrm{C}$ ) wheat bran

$86(1: 3(\mathrm{v} / \mathrm{v})$ ratio, as previously described (Jung et al. 2014).

\section{$87 \quad$ Insects}

88 Larvae were provided by Micronutris (St-Orens, France) and fed with heat-sterilized bran before the

89 experiment. As it was not possible to determine their precise developmental stage, but we used only

90 larvae weighing between 20 and $50 \mathrm{mg}$, which should correspond to 13th or 14th instar individuals

91 (Huang et al. 2011).

\section{Rearing of T. molitor larvae in soil samples}

93 We maintained laboratory-reared T. molitor larvae for five days in sterilized wheat bran mixed with

94 soil samples. During this period, the larvae were incubated at $15{ }^{\circ} \mathrm{C}$ in the same humidity

95 conditions. They were then starved for 24 hours (Figure 1D) to exclude individuals that were

96 infected with pathogens (which would have died within this 24 hours period) and to limit the risk

97 that the DNA we extract comes from the larval alimentary bolus. This starvation period potentially

98 induces a stress on insect larvae, which might in turn impact their microbiota. We imposed it on all

99 insects, so that the potential bias it creates is identical in all treatments.

100 Control insects were reared in the same conditions than other insects except that they were

101 incubated in sterile wheat bran, with no soil mixed. Control insects microbiota should thus be close

102 to what it was for all insects before the experiment.

\section{DNA extraction}

104 We extracted DNA from two randomly sampled insects per box (which makes a total of 24 insects 
bioRxiv preprint first posted online Sep. 21, 2018; doi: http://dx.doi.org/10.1101/423178. The copyright holder for this preprint

(which was not peer-reviewed) is the author/funder, who has granted bioRxiv a license to display the preprint in perpetuity.

All rights reserved. No reuse allowed without permission.

105 per site) and 5 control insects. However, we failed to amplify 16S rRNA during PCR step for 2

106 samples, ending with 24 samples for CDS, 22 samples for MTF and 5 controls. Insect larvae were

107 sterilized in 70\% ethanol, rinsed in water and then killed. The guts of the larvae were dissected in

108 sterile Ringer solution (Jung et al. 2014). Dissection tools were sterilized with 70\% ethanol between

109 insects. Dissected guts were placed in an Eppendorf tube with $100 \mu \mathrm{L}$ of lysis solution and $1 \mu \mathrm{L}$

110 lyzozyme (Quick Extract, Bacterial DNA extraction TEBU-BIO) and ground with $3 \mathrm{~mm}$ steel beads

111 for 30 seconds at $20 \mathrm{~Hz}$ with a TissueLyzer (Qiagen). The resulting homogenates were incubated at

112 room temperature for two days, then frozen in liquid nitrogen and heated at $95{ }^{\circ} \mathrm{C}$ to ensure that all

113 the cells were lysed. DNA was prepared by the phenol-chloroform-alcohol and chloroform

114 extraction method. The DNA was resuspended in sterile water and quantified with a NanoDrop

115 spectrometer (Thermo Fisher Scientific). We performed extraction blanck controls using DNA-free

116 water.

\section{16S and gyrB DNA amplification}

118 We targeted the V3-V4 region of the 16S rRNA gene, which is classically used for bacterial

119 identification in microbial ecology studies, as clean and complete reference databases are available

120 for this region. We also used the bacterial housekeeping gene $g y r B$, to support the data for the $16 \mathrm{~S}$

121 rRNA (Barret et al. 2015). The V3-V4 region of the 16S rRNA gene was amplified with the

122 PCR1F_460 (5’-ACGGRAGGCAGCAG-3’) / PCR1R_460 (5’-TACCAGGGTATCTAATCCT-3’)

123 primers (modified versions of the primers used in a previous study Klindworth et al. (2012)).

124 Amplification was performed with the MTP Taq polymerase (Sigma, ref 172-5330), according to

125 the manufacturer's protocol, with $1 \mu \mathrm{L}$ of $1 / 10$ diluted DNA extract for each sample. The PCR

126 protocol used for these primers was $60 \mathrm{~s}$ at $94{ }^{\circ} \mathrm{C}$, followed by 30 cycles of $60 \mathrm{~s}$ at $94{ }^{\circ} \mathrm{C}, 60 \mathrm{~s}$ at 65

$127{ }^{\circ} \mathrm{C}$, $60 \mathrm{~s}$ at $72{ }^{\circ} \mathrm{C}$, and then $10 \mathrm{~min}$ at $72{ }^{\circ} \mathrm{C}$. The gyrB gene was amplified with primers described

128 elsewhere: gyrB_aF64 5'-MGNCCNGSNATGTAYATHGG-3' and gyrB_aR353 5’- 
bioRxiv preprint first posted online Sep. 21, 2018; doi: http://dx.doi.org/10.1101/423178. The copyright holder for this preprint

(which was not peer-reviewed) is the author/funder, who has granted bioRxiv a license to display the preprint in perpetuity.

All rights reserved. No reuse allowed without permission.

ACNCCRTGNARDCCDCCNGA-3' (Barret et al. 2015). Amplification was performed with the iProof High-Fidelity Taq polymerase (Bio-Rad, ref. 172-5301), according to the manufacturer's protocol, with $1 \mu \mathrm{L}$ of 1/10 diluted DNA extract for each sample. The PCR protocol used for these primers was $30 \mathrm{~s}$ at $98{ }^{\circ} \mathrm{C}$, followed by 40 cycles of $10 \mathrm{~s}$ at $98{ }^{\circ} \mathrm{C}, 30 \mathrm{~s}$ at $60{ }^{\circ} \mathrm{C}, 30 \mathrm{~s}$ at $72{ }^{\circ} \mathrm{C}$, and then 10 min at $72{ }^{\circ} \mathrm{C}$. For each PCR, we performed negative and positive controls with water and bacterial DNA extracted from a pure culture of Xenorhabdus nematophila (Enterobacteriaceae), respectively, and checked PCR amplicons by electrophoresis in a 1\% agarose gel. We performed technical replicates for the PCR and sequencing steps and obtained identical microbiota patterns (see Additional File 2, for example). Amplicon libraries were sequenced by the GeT-Plage genomics platform at Genotoul (Toulouse, France) with Illumina MiSeq technology and a 2x250 bp kit. Raw sequence data of both 16S rRNA and gyrB are available from http://www.ebi.ac.uk/ena/data/view/PRJEB21797.

\section{Metabarcoding data treatment}

Sequence data for both markers were analyzed with OBITools (Boyer et al. 2015). Raw paired-end reads were aligned and merged, taking into account the phred quality score of each base to compute an alignment score. Reads with a low alignment score (>50), containing unknown bases or with an unexpected size (outside 400 bp and 470 bp, and 230 bp and 260 bp after primer trimming for the 16S rRNA gene and gyrB respectively) were removed from the dataset. After primer trimming, singletons (i.e. sequences only found once in the dataset) were removed (Auer et al. 2017). Sequences were then clustered into OTUs with the Sumaclust algorithm (Mercier et al. 2013), using a 97\% similarity threshold (OBITools workflows and the raw count table are available in Additional Files 3 and 4). We then removed from the datasets all clusters containing less than $0.005 \%$ of the total number of reads (Bokulich et al. 2013). The remaining OTUs were assigned to a taxonomic group with RDPclassifier (Wang et al. 2007) and the RDPII reference database for the 16S rRNA 
bioRxiv preprint first posted online Sep. 21, 2018; doi: http://dx.doi.org/10.1101/423178. The copyright holder for this preprint

(which was not peer-reviewed) is the author/funder, who has granted bioRxiv a license to display the preprint in perpetuity.

All rights reserved. No reuse allowed without permission.

153 marker and with seq_classifier.py from the mothur pipeline (Schloss et al. 2009) and the reference

154 database from Barret et al. (2015) for gyrB gene (OTU assignments are available in Additional File 155 5).

\section{Quantitative PCR analysis}

157 To check for changes in OTU abundances, we performed quantitative PCR (qPCR) on two 158 randomly picked insects per soil subsample among those used in the metabarcoding analysis. The 159 sampling probability for each sample was adjusted for the total number of 16S rRNA reads for the sample. The five DNA samples corresponding to control insects were all analyzed.

All qPCRs were performed in triplicate, with $3 \mu \mathrm{L}$ of reaction mixture, on a LightCycler480 machine (Roche Diagnostics), after the plate had been filled by an Echo 525 liquid handler (Labcyte). The reagent concentrations were identical in all SYBR Green I assay reactions: 1X Light-Cycler 480 SYBR Green I Master Mix (Roche Diagnostics), $500 \mathrm{nM}$ each of the forward and reverse primers specific for genus Pseudomonas (here named Pse -16S, Bergmark et al. (2012)), the Enterobacteriaceae family (here named Entero-rplP, Takahashi et al. (2017)) or the Eubacteria kingdom (here named uni16S, Vandeputte et al. (2017)) (see sequences in Additional File 6) and DNA matrix. The DNA used was either genomic DNA $(0.5 \mathrm{ng} / \mu \mathrm{L})$ from the various reference strains, to check primer specificity (Escherichia coli, Serratia marcesens, Klebsiella pneumoniae, Salmonella typhimurium, Enterobacter cloacae, Pseudomonas protegens, Stenotrophomonas,

171 Acinetobacter, Enterococcus ) or a 1/100 dilution of insect gut DNA for metabarcoding. The qPCR 172 conditions were 10 minutes at $95^{\circ} \mathrm{C}$, followed by 45 cycles of $5 \mathrm{~s}$ at $95^{\circ} \mathrm{C}, 10 \mathrm{~s}$ at $62{ }^{\circ} \mathrm{C}$ and $15 \mathrm{~s}$ at $17372{ }^{\circ} \mathrm{C}$, with a final dissociation curve segment. Cycle threshold (Ct) values were determined with 174 Light-Cycler 480 software. After the validation of primer specificity $(13<\mathrm{Ct}<37$ for positive 175 controls, $\mathrm{Ct}>40$ for negative controls), absolute quantifications were calculated by the standard 176 curve method. Serial dilutions of standard samples consisting of genomic DNA from E. coli 
bioRxiv preprint first posted online Sep. 21, 2018; doi: http://dx.doi.org/10.1101/423178. The copyright holder for this preprint

(which was not peer-reviewed) is the author/funder, who has granted bioRxiv a license to display the preprint in perpetuity.

All rights reserved. No reuse allowed without permission.

177 ATCC25922 for the rplP gene and the rRNA16S gene (uni16S primers) and genomic DNA from

178 Pseudomonas aeruginosa CIP76.110 (=ATCC27853) for the 16S rRNA gene (Pse -16S primers)

179 were prepared and used for calibration. The gene copy number of the target gene ( $G C N_{\text {target }}$

180 [copies]) in standard samples was estimated using the total amount of genomic DNA in the

181 calibration samples $M_{D N A} \quad$ [g], the size of the bacterial chromosome $L_{D N A} \quad$ [bp], the number

182 of targets per bacterial chromosome $\quad n_{\text {target }} \quad$ [copies], Avogadro’s constant $N_{A}\left(6.022 \times 10^{23}\right.$

$\left.183 \mathrm{bp} \mathrm{mol}{ }^{-1}\right)$ and the mean weight of a double-stranded base pair $M_{b p} \quad\left(660 \mathrm{~g} \mathrm{~mol}^{-1} \mathrm{bp}^{-1}\right)$ as follows:

$$
G C N_{\text {target }}=\frac{N_{A} \times M_{D N A}}{L_{D N A} \times M_{b p}} \times n_{\text {target }}
$$

185 Using the parameters of the curves linking $G C N_{\text {target }}$ and $C t$ in standard samples, we then

186 estimated the GCN of target genes in our gut samples. This estimation was possible because PCR 187 efficiency (PE) was very close to that for standard samples (Additional File 6).

\section{Community analysis}

189 All analyses were performed with R version 3.3.3 (R Core Team 2015) (see Additional File 7 and 8

190 for the overall workflow). We did not rarefy data (McMurdie and Holmes 2014), but we used

191 Chao1 index which is the estimated OTU richness of each sample, taking into account the possible

192 lack of detection of some rare OTUs. Chao1 index is thus the observed OTU richness per insect 193 plus an estimation of the unseen OTUs per insect. The Shannon index is based on relative 194 abundance data, to represent the effective OTU richness of the sample based on the predominant 195 OTUs. We estimated the Chao1 and Shannon alpha diversity indices with the vegan package of $\mathrm{R}$ 196 (Oksanen et al. 2017). We also calculated Pielou's eveness which is the Shannon diversity divided 197 by the natural logarithm of the OTU richness of the sample, and reflects how similar the relative 198 abundances of OTUs in a sample are. 
bioRxiv preprint first posted online Sep. 21, 2018; doi: http://dx.doi.org/10.1101/423178. The copyright holder for this preprint

(which was not peer-reviewed) is the author/funder, who has granted bioRxiv a license to display the preprint in perpetuity.

All rights reserved. No reuse allowed without permission.

199 We calculated the beta diversity distance matrix from the Jaccard and Bray-Curtis distances for

200 presence/absence and relative abundance data, respectively, using the vegan package. We also

201 computed Unifrac and wUnifrac distances for presence/absence and relative abundance data,

202 respectively (Lozupone and Knight 2005), with the Phyloseq package (McMurdie and Holmes

203 2013). Unifrac and wUnifrac distances include phylogenetic distances between pairs of OTUs. A

204 phylogenetic tree of the OTU sequences was, therefore, required. We generated this tree by aligning

205 OTU sequences with Seaview software and the muscle method. The phylogenetic tree was built

206 with RAxML and the GTRCAT substitution model for nucleotide sequences (Stamatakis 2014)

207 (Additional File 9). Differences in the gut bacterial community between soil-reared insects and

208 control insects were evaluated based on the beta diversity distance matrix, in PERMANOVA tests

209 implemented in the vegan package (Oksanen et al. 2017), with treatment as the explanatory

210 variable. We investigated differences between the gut bacterial communities of soil-reared insects,

211 by performing PERMANOVA tests on distance matrices with two explanatory variables: soil

212 sample (i.e. CDS or MTF) and soil subsample (i.e. CDS1-3, MTF1-3). Beta-diversity distances

213 were represented using a PcoA analysis from the vegan package (Oksanen et al. 2017).

\section{Results}

215 Incubation of T. molitor larvae with soil increases the richness and 216 diversity of their gut microbiota

217 After cleaning, the total dataset of the metabarcoding experiment contained 792,395 sequences

218 clustered into 106 bacterial OTUs. Rarefaction curves showed that most of the samples had reached

219 the saturation plateau (Figure 2A). We used the Chao1 index, which assesses the extrapolated

220 richness of OTUs, including an estimation for undetected rare OTUs, to compare alpha diversity

221 between soil-reared and control insects. The mean Chao1 index of the microbiota of soil-reared 
bioRxiv preprint first posted online Sep. 21, 2018; doi: http://dx.doi.org/10.1101/423178. The copyright holder for this preprint

(which was not peer-reviewed) is the author/funder, who has granted bioRxiv a license to display the preprint in perpetuity.

All rights reserved. No reuse allowed without permission.

222 insects (MTF and CDS) was a $48 \pm 13$ OTUs whereas that of control insects (BRAN) was 25

$223 \pm 9$ OTUs (Figure 2B). The OTU richness of the gut microbiota therefore increased significantly

224 after the incubation of the insects with soil samples (Chao1 index, soil vs. control: Wilcoxon rank

225 sum test, $\mathrm{W}=221$, p-value $=1 \mathrm{e}-3)$. A similar conclusion was drawn for analyses based on the

226 Shannon index, which reflects relative OTU abundance within samples (Figure 2B, soil vs. control:

227 Wilcoxon rank sum test, $\mathrm{W}=216$, p-value $=1 \mathrm{e}-3)$. Moreover, control insects harbored bacterial

228 communities dominated by a very small number of dominant OTUs (low Shannon index $\simeq 0.2$

229 and low Pielou's eveness $\simeq 0.02$ ). OTU assignment identified these dominant OTUs as

230 belonging to the Pseudomonadaceae family (Figure 2C). By contrast, soil-reared insects harbored

231 bacterial communities with more balanced relative OTU abundances (Shannon index $\simeq 1.7$ ).

232 The gut microbiota of these insects was dominated by Enterobacteriaceae, together with

233 Pseudomonadaceae and other less frequent families, such as Moraxellaceae and Aeromonadaceae

234 (Figure 2C). This was confirmed by the analysis of Pielou's eveness index which was significantly

235 lower in control insects than in soil-reared insects (Wilcoxon rank sum test, $\mathrm{W}=0$, p-value $=7.6 \mathrm{e}-7$ ).

236 Thus, five days in soil significantly increased the richness of the microbiota in the gut of T. molitor

237 larvae, and modified the balance of OTUs present.

238 We also investigated the effect of soil treatments according to soil origin, by comparing the alpha 239 diversity of CDS and MFT samples. The Chao1 and Shannon indices were significantly lower in

240 MTF than in CDS samples (Figure 2B; Chao1 index: Kruskal-Wallis test, $\chi^{2}=12.93$, p-value = 241 3e-4; Shannon index: Kruskal-Wallis test, $\quad x^{2}=9.6136, p$-value $\left.=1 e-3\right)$. The CDS and MTF 242 soils had therefore different impacts on both richness and bacterial balance.

243 Soil treatment induces a change in microbiota composition that is 244 variable between soil sampling sites

245 We investigated the effect of soil treatment on insect microbiota, by calculating the beta-diversity 
bioRxiv preprint first posted online Sep. 21, 2018; doi: http://dx.doi.org/10.1101/423178. The copyright holder for this preprint

(which was not peer-reviewed) is the author/funder, who has granted bioRxiv a license to display the preprint in perpetuity.

All rights reserved. No reuse allowed without permission.

246 between insect gut microbiota with various distance indices (Figure 3). We first calculated a

247 distance based on pairwise Jaccard and Bray-Curtis distances. These two indices are

248 complementary, because Jaccard distance depends purely on the presence/absence of OTUs,

249 whereas Bray-Curtis distance also takes into account the number of reads for each OTU as a proxy

250 for their relative abundance. We performed PCoA analysis on distance matrices (Figure 3A) where

251 control insects tended to cluster together. PERMANOVA analysis confirmed that community

252 composition differed between soil-reared insects and control insects (13 to 19\% of the variance

253 explained by soil treatment, Table 1A).

254 The microbiota profiles of insects placed in soils from the same site (i.e. CDS or MTF) or in the

255 same soil subsample (e.g. CDS1, CDS2 or CDS3) did not cluster together perfectly. However, a

256 second PERMANOVA model for these samples identified two explanatory factors, soil sampling

257 site (i.e. CDS or MTF) and subsample identity (e.g. CDS1, CDS2 or CDS3), as having a significant

258 impact on gut community composition (Table 1B). Indeed, sample site explained 14 and $8 \%$ of the

259 variance and soil subsample explained 17 and 18\% of the variance, for the Jaccard and Bray-Curtis

260 indices, respectively.

261 As reported above, the soil-reared insects had a microbiota dominated by Enterobacteriaceae

262 (Figure 2C). We thus estimated Unifrac distances, which take into account the phylogenetic

263 distances between OTUs, and wUnifrac distances, which also take relative OTU abundance into

264 account. With these corrections, the differences between control insects and soil-reared insects were

265 significant only when relative OTU abundance was taken into account (Figure 3; Table 1A). Subtle

266 but significant effects of sample site and soil subsample on community composition were also

267 observed with the Unifrac and wUnifrac indices (Figure 3; Table 1B).

268 Overall, our results show that soil treatment changes the community composition of the gut

269 microbiota and that this change is detectable despite inter-individual variability. The bacterial

270 communities present in the gut differ both between sample sites and between soil subsamples. 
273 We then pooled all individuals of a given treatment to determine which OTUs are found in at least

274 one individual for each treatment. The 47 OTUs found in control insects were also present in the

275 insects of the soil treatment groups (Figure 4A). The 44 OTUs common to all three conditions

276 matched 97\% of the reads for soil-reared insects (gray area in Figure 4B and Figure 4C). However,

277 after soil treatment, Pseudomonas, the dominant OTU in control insects (98\% of the reads)

278 accounted for only 27 and 23\% of the reads in CDS and MTF samples, respectively (Figure 4C).

279 Conversely, Serratia species, together with the Enterobacter group, which accounted for less than

$2801 \%$ of sequence reads in controls, accounted for $35 \%$ and $43 \%$ of the reads for CDS and MTF,

281 respectively.

282 For confirmation of our initial metabarcoding results, we performed a second metabarcoding 283 analysis with another marker, a 300 bp region of the gyrB housekeeping gene (see Additional File

284 1). This single-copy marker has been shown to provide assignments to more precise taxonomic

285 levels than the 16S rRNA gene (Barret et al. 2015). In accordance with the results obtained with the

286 16S rRNA gene marker, Pseudomonas was the dominant OTU in control insects (more than $99 \%$ of

287 the reads) and its relative abundance was lower in soil-reared insects (CDS: $14 \%$ MTF: $17 \%$ of the

288 reads). The genus Serratia and the Enterobacter group accounted for less than $0.06 \%$ of the reads

289 in control insects and a large proportion of those for the insects in the two soil treatment groups

290 (CDS: $57 \%$ MTF:70 \% of the reads).

291 Finally, we also identified with 16S rRNA 59 OTUs that were not detectable in control insects but

292 were present at low abundance (3\% of the reads) in at least one soil-reared insect (red dashed area

293 in Figure 4B and Figure 4D). These OTUs may correspond to taxa that were absent from the insects

294 before soil treatment, and that colonized the insect gut during incubation in soil. Alternatively, they 
bioRxiv preprint first posted online Sep. 21, 2018; doi: http://dx.doi.org/10.1101/423178. The copyright holder for this preprint

(which was not peer-reviewed) is the author/funder, who has granted bioRxiv a license to display the preprint in perpetuity.

All rights reserved. No reuse allowed without permission.

295

296

297

298

299

300

301

302

303

304

305

306

307

308

309

310

311

312

313

314

315

318

may have been present in the control insects at densities below the PCR detection threshold. Their abundance would then have increased above this threshold during incubation, just like the abundances of Serratia or Enterobacter. Overall, our data strongly suggest that the main effect of soil treatment is a change in the relative abundances of OTUs, although low levels of bacterial colonization from soil cannot be ruled out.

\section{The balance between members of the resident OTUs contributes to the}

\section{variation of abundances after soil treatment}

We assessed the variation of OTU balance after soil treatment further, by quantifying the bacterial taxonomic groups present in all treatments but with different relative abundances between the two contrasting sets of conditions studied (control versus soil-reared). We first characterized the gut resident microbiota in our larvae, as the OTUs present in at least $95 \%$ of our samples (following (Falony et al. 2016)). Based on 16S rRNA gene metabarcoding, we identified five resident OTUs: four Enterobacteriaceae (Enterobacterericeae 1, Enterobacterericeae 2, Serratia and Enterobacter group) and Pseudomonas. The resident OTUs obtained with the gyrB gene consisted of two OTUs, Pseudomonas and Serratia, confirming the existence of an invariant bacterial population in our insect gut microbiota. Based on the composition of this resident microbiota, we chose to monitor Pseudomonas and the Enterobacteriaceae to check for changes in the abundance of these bacteria following treatment. We performed quantitative PCR (qPCR) on a subset of 17 samples, including the five control insects and two insects for each soil subsample. We first calculated the gene copy number (GCN) of the 16S rRNA gene in each sample, using a universal primer pair targeting Eubacteria (uni16S primers). As the number of 16S rRNA gene copies varies across Eubacteria lineages (between 1 and 15 copies per genome, Lee et al. (2008)), the GCN cannot be used to quantify the number of bacterial cells with precision (Angly et al. 2014). However, in our samples, GCN/ $\mu \mathrm{L}$ ranged from $10^{7}$ to $10^{8}$ and did not differ significantly between samples (Kruskal- 
bioRxiv preprint first posted online Sep. 21, 2018; doi: http://dx.doi.org/10.1101/423178. The copyright holder for this preprint

(which was not peer-reviewed) is the author/funder, who has granted bioRxiv a license to display the preprint in perpetuity.

All rights reserved. No reuse allowed without permission.

319 Wallis rank sum test, chi squared $=2.66, \mathrm{df}=2$, $\mathrm{p}$-value $=0.26$ ), which suggests that the total

320 number of bacteria was similar in our 17 samples. We then targeted a region of the 16S rRNA gene

321 specific to the Pseudomonas genus, (Pse -16S: 251 nucleotides of the V3-V4 hypervariable region,

322 with 4 to 7 copies per genome Bodilis et al. 2012), and a region of the rplP gene, region specific to

323 the Enterobacteriaceae family (Entero-rplP : 185 nucleotides of the rplP gene, one copy by

324 genome). The Pse-16S GCN in soil-reared insects was one tenth that in control insects (Figure 5A).

325 Conversely, the Entero-rplP GCN was 100 times higher in soil-reared insects (Figure 5B). Soil

326 acclimation therefore seems to induce a decrease in Pseudomonas abundance and an increase in

327 Enterobacteriaceae abundance. Our data suggest that the main effect of soil treatment is to modify

328 the relative abundances of the resident bacterial communities of the gut microbiota.

\section{Discussion}

330 Rearing larvae in soil rather than in bran caused major changes in gut microbiota structure. Soil-

331 reared larvae have a richer and more diverse gut microbiota than control larvae. Despite

332 considerable inter-individual variability, we found that the changes in community composition

333 depended on both the site from which the soil was obtained, and the precise soil subsample used.

334 An analysis of the OTUs found in the different samples suggested that the main effect of the soil

335 treatment was a change in the relative abundance of OTUs. We confirmed this trend by qPCR for

336 the two main taxonomic groups displaying changes in abundance: the Enterobacteriaceae family

337 and the genus Pseudomonas, which predominated in soil-reared insects and in the control,

338 respectively.

339 Our rearing conditions (laboratory versus soil acclimatization) were associated with two types of

340 gut microbial patterns, consistent with previous findings for laboratory-reared and wild insects. On

341 the one hand, gut microbiota communities of laboratory-reared insects, which are usually

342 maintained on very simple media and diets, are dominated by one or two bacterial strains: 
bioRxiv preprint first posted online Sep. 21, 2018; doi: http://dx.doi.org/10.1101/423178. The copyright holder for this preprint

(which was not peer-reviewed) is the author/funder, who has granted bioRxiv a license to display the preprint in perpetuity.

All rights reserved. No reuse allowed without permission.

343 Pseudomonas in our study, Enterococcus in moths (Chen et al. 2016; Staudacher et al. 2016) or the

344 Enterobacteriaceae group Orbus in fruit flies (Chandler et al. 2011). On the other hand, following

345 soil treatment, our larvae harbored more complex community profiles, with several

346 Enterobacteriaceae together with the Pseudomonas strain that we found in control insects. Wild

347 coleopterans, such as the forest cockchafer, Melolontha hippocastani, which has a soil-dwelling

348 larval stage, have a microbiota dominated by Enterobacteriaceae, essentially a consortium of

349 Serratia, and a Shannon diversity index close to that observed here for soil-reared insects (Arias-

350 Cordero et al. 2012). Other coleopterans, such as Agrilus planipennis and Nicrophorus vespiloides

351 (Vasanthakumar et al. 2008; Wang and Rozen 2017), both sampled from the wild and reared on a

352 natural diet, also have microbiotas dominated by Pseudomonas sp., the Enterobacter group and

353 Serratia sp.. These findings suggest that our protocol can be used to mimic soil-dwelling insects

354 effectively with reared insects. This might make it possible to obtain large numbers of individuals

355 while working on a relevant set of bacteria in further studies of the insect gut microbiota. Moreover,

356 we focused here on the gut microbiota, but soil treatment probably modifies the entire microbiota,

357 including the cuticular bacterial community. Our methodology is therefore likely to be of particular

358 interest for holobiont studies (Bordenstein and Theis 2015) involving controlled hypothesis-driven

359 experiments on insects with a relevant total bacterial community.

360 The changes we observed in gut microbiota structure may result from major changes in insect diet, as insects may have access to different sources of food when incubated in soil compared to sterile

362 bran. Our results fit well to the diet influences on microbiota documented in several Drosophila 363 species (Chandler et al. 2011; Staubach et al. 2013; Vacchini et al. 2017), omnivorous cockroaches 364 (Pérez-Cobas et al. 2015), termites (Mikaelyan et al. 2015), lepidopterans (Broderick et al. 2004; 365 Belda et al. 2011; Priya et al. 2012) and a few coleopterans (Colman et al. 2012; Jung et al. 2014; 366 Franzini et al. 2016; Kim et al. 2017). Changes in microbiota structure could also depend on 367 physiochemical properties of the insect gut. In wood-feeding cockroaches, different parts of 
bioRxiv preprint first posted online Sep. 21, 2018; doi: http://dx.doi.org/10.1101/423178. The copyright holder for this preprint

(which was not peer-reviewed) is the author/funder, who has granted bioRxiv a license to display the preprint in perpetuity.

All rights reserved. No reuse allowed without permission.

368 intestinal tract showed differences in $\mathrm{pH}$, redox potential and hydrogen contents, and were

369 associated to different bacterial communities (Bauer et al. 2015). The ingestion of soil particles

370 probably modifies some of these properties of the gut. The fact that the soil characteristics differed

371 between the two sampling sites (low sand/silt ratio for Causse-De-La-Selle (CDS), and higher

372 sand/silt ratio for Montferrier (MTF)) could thus explain in part their different impacts on T. molitor

373 gut microbiota.

374 The changes in the gut bacterial population may depend not only on treatment, but also on the

375 bacterial community initially present in the gut. Previous studies (Jung et al. 2014; Osimani et al.

376 2018) showed that a Spiroplasma species predominated in the gut microbiota of the larval lineage,

377 even after and environmental change. Spiroplasma has been shown to be a heritable endosymbiont

378 in Drosophila (Mateos et al. 2006). Similar effects were observed for other endosymbionts, such as

379 Wolbachia, Cardinium, Blattabacterium-like and putative Bartonella-like symbionts in mites

380 Tyrophagus putrescentiae following dietary changes (Erban et al. 2017). In all these case,

381 endosymbiont seem to impede major shifts in the gut microbiota or conceal changes in frequencies

382 that may occur in low-abundance OTUs. This effect is absent in our experiment, probably because

383 the insects we used are associated to Spiroplasma or any other endosymbiotic bacteria.

384 Our results also provide interesting insight into the spatial variation of the gut bacterial community

385 in insect populations. The differences observed after incubation in soil from different plots were consistent with the findings of other studies on coleopterans, in which the dissimilarity of the gut bacterial community between individuals is correlated with the distance between sampling sites (Adams et al. 2010). However, we also observed a difference in the gut microbiota between insects incubated with soils collected a few meters apart, at the same sampling site, and this difference was detectable despite high levels of inter-individual variation. Minor environmental differences thus

391 have a detectable impact on the gut microbiota and structure this microbiota within insect 392 populations over very small geographic scales. 
bioRxiv preprint first posted online Sep. 21, 2018; doi: http://dx.doi.org/10.1101/423178. The copyright holder for this preprint

(which was not peer-reviewed) is the author/funder, who has granted bioRxiv a license to display the preprint in perpetuity.

All rights reserved. No reuse allowed without permission.

393 Overall, our experiments indicate that gut microbiota can be readily changed by modifying the

394 environment in which the insects are living. We identified resident taxa present in all the

395 environments we tested. These taxa change in relative abundance with environmental changes. The

396 range of environmental conditions tested here is narrower than that experienced by insects in the 397 wild, but results suggest that, following changes in environmental conditions, the insect gut 398 microbiota maintains a stable composition, but displays plasticity in terms of its structure.

\section{Availability of data and material}

400 Both the 16S rRNA and gyrB datasets generated and analyzed in this study are available from the 401 ENA (European Nucleotide Archive) repository, http://www.ebi.ac.uk/ena/data/view/PRJEB21797

\section{Funding}

403 MC obtained PhD funding from the French Ministry of Higher Education, Research and Innovation.

404 Metabarcoding sequencing was funded by the MEM-INRA metaprogram (P10016). This work was 405 also supported by the French Laboratory of Excellence project “TULIP” (ANR-10-LABX-41 ; 406 ANR-11-IDEX-0002-02)

\section{Authors' contributions}

408 MC, JBF and SG conceived the study. MC designed and performed the experiments. AL performed 409 qPCR analysis. MC and JCO analyzed the data. JBF and SG supervised the project. All authors 410 wrote, read and approved the final manuscript. 


\section{Acknowledgments}

412 413

We thank Marie Frayssinet for help with soil sampling and insect acclimatization, and Lucie Zinger for help with data analysis.

\section{References}

Adams, A. S., Adams, S. M., Currie, C. R., Gillette, N. E. and Raffa, K. F. 2010. Geographic variation in bacterial communities associated with the red turpentine beetle (Coleoptera: Curculionidae). Environmental entomology 39, 406-414.

Alberdi, A., Aizpurua, O., Bohmann, K., Zepeda-Mendoza, M. L., and Gilbert, M. T. P. 2016. Do vertebrate gut metagenomes confer rapid ecological adaptation?. Trends Ecol Evol 31, 689 699.

Angly, F. E., Dennis, P. G., Skarshewski, A., Vanwonterghem, I., Hugenholtz, P. and Tyson, G. W. 2014. CopyRighter: a rapid tool for improving the accuracy of microbial community profiles through lineage-specific gene copy number correction. Microbiome 2, 11.

Arias-Cordero, E., Ping, L., Reichwald, K., Delb, H., Platzer, M. and Boland, W. 2012. Comparative evaluation of the gut microbiota associated with the below-and above-ground life stages (larvae and beetles) of the forest cockchafer, Melolontha hippocastani. PLoS ONE 7, e51557.

Auer, L., Mariadassou, M., O'Donohue, M., Klopp, C. and Hernandez-Raquet, G. 2017. Analysis of large 16S rRNA Illumina datasets: impact of singleton read filtering on microbial community description. Mol Ecol Resour, 00:1-11.

Barret, M., Briand, M., Bonneau, S., Préveaux, A., Valière, S., Bouchez, O., Hunault, G., Simoneau, P. and Jacques, M. A. 2015. Emergence shapes the structure of the seed microbiota. Appl Environ Microbiol 81, 1257-1266.

Bauer, E., Lampert, N., Mikaelyan, A., Köhler, T., Maekawa, K. and Brune, A. 2015. Physicochemical conditions, metabolites and community structure of the bacterial microbiota in the gut of wood-feeding cockroaches (Blaberidae: Panesthiinae). FEMS Microbiol Ecol 91, 1-14.

Belda, E., Pedrola, L., Peretó, J., Martínez-Blanch, J. F., Montagud, A., Navarro, E., Urchueguía, J., Ramón, D., Moya, A. and Porcar, M. 2011. Microbial diversity in the midguts of field and lab-reared populations of the european corn borer Ostrinia nubilalis. PLoS ONE 6, 1-14.

Belizário, J. E. and Napolitano, M. 2015. Human microbiomes and their roles in dysbiosis, common diseases, and novel therapeutic approaches. Front Microbiol 6.

Bergmark, L., Poulsen, P. H. B., Al-Soud, W. A., Norman, A., Hansen, L. H. and Sørensen, S. J. 2012. Assessment of the specificity of Burkholderia and Pseudomonas qPCR assays for detection of these genera in soil using 454 pyrosequencing. FEMS Microbiol Lett 333, 77-84. 
444 Bokulich, N. A., Subramanian, S., Faith, J. J., Gevers, D., Gordon, J. I., Knight, R., Mills, D. 445 A. and Caporaso, J. G. 2013. Quality-filtering vastly improves diversity estimates from Illumina amplicon sequencing. Nat Methods 10, 57.

Bordenstein, S. R. and Theis, K. R. 2015. Host biology in light of the microbiome: ten principles of holobionts and hologenomes. PLoS Biol 13, e1002226.

Boyer, F., Mercier, C., Bonin, A., Le Bras, Y., Taberlet, P. and Coissac, E. 2015. obitools: a unixinspired software package for DNA metabarcoding. Mol Ecol Resour 16, 176-182.

Broderick, N. A., Buchon, N. and Lemaitre, B. 2014. Microbiota-induced changes in Drosophila melanogaster host gene expression and gut morphology. MBio 5, e01117-14.

Broderick, N. A., Raffa, K. F., Goodman, R. M. and Handelsman, J. 2004. Census of the bacterial community of the gypsy moth larval midgut by using culturing and culture-independent methods. Appl and Environ Microbiol 70, 293-300.

Caccia, S., Di Lelio, I., La Storia, A., Marinelli, A., Varricchio, P., Franzetti, E., Banyuls, N., Pennacchio, F. 2016. Midgut microbiota and host immunocompetence underlie Bacillus thuringiensis killing mechanism. P Natl Acad Sci USA 113, 9486-9491.

Candela, S., Biagi, E., Maccaferri, S., Turroni, S. and Brigidi, P. 2012. Intestinal microbiota is a plastic factor responding to environmental changes. Trends Microbiol 20, 385 - 391. communities of diverse Drosophila species: ecological context of a host-microbe model system. PLoS Genet 7, e1002272.

Chen, B., Teh, B. S., Sun, C., Hu, S., Lu, X., Boland, W. and Shao, Y. 2016. Biodiversity and activity of the gut microbiota across the life history of the insect herbivore Spodoptera littoralis. Sci Rep 6, 29505.

Colman, D. R., Toolson, E. C. and Takacs-Vesbach, C. D. 2012. Do diet and taxonomy influence insect gut bacterial communities?. Mol Ecol 21, 5124-5137.

Engel, P. and Moran, N. 2013. The gut microbiota of insects--diversity in structure and function. FEMS Microbiol Rev 37, 699-735.

Erban, T., Ledvinka, O., Nesvorna, M. and Hubert, J. 2017. Experimental manipulation shows a greater influence of population than dietary perturbation on the microbiome of Tyrophagus putrescentiae. Appl Env Microbiol 83, e00128-17.

Erkosar, B. and Leulier, F. 2014. Transient adult microbiota, gut homeostasis and longevity: novel insights from the Drosophila model. FEBS Lett 588, 4250-4257. The Gut microbiomes of two Pachysoma Macleay desert dung beetle species (Coleoptera: Scarabaeidae: Scarabaeinae) feeding on different diets. PLoS ONE 11, e0161118. 
480 Hedin, C., van der Gast, C. J., Rogers, G. B., Cuthbertson, L., McCartney, S., Stagg, A. J., 481 Lindsay, J. O. and Whelan, K. 2015. Siblings of patients with Crohn's disease exhibit a 482 biologically relevant dysbiosis in mucosal microbial metacommunities. Gut, gutjnl-2014.

483 Huang, Q., Hu, J., Zhou, D. G., Ling, S., Ruan, H. B., Wang, X. N., Chen, G., Zhu, T. H., Yang, 484 C. P. and Yang, W. 2011. Comparison of growth, development, survivorship and food utilization of 485 two color varieties of Tenebrio molitor (Coleoptera: Tenebrionidae). Acta Entomol Sinica 3, 008.

Huang, S. and Zhang, H. 2013. The impact of environmental heterogeneity and life stage on the hindgut microbiota of Holotrichia parallela larvae (Coleoptera: Scarabaeidae). PloS ONE 8, 1-14.

Jung, J., Aram, H., Park, Y. W., Kim, Y. J., Koh, H. and Woojun, P. 2014. Gut microbiota of Tenebrio molitor and their response to environmental change. J Microbiol Biotechnol 24, 888-897.

Kim, J. M., Choi, M. Y., Kim, J. W., Lee, S. A., Ahn, J. H., Song, J., Kim, S. H. and Weon, H. Y. 2017. Effects of diet type, developmental stage, and gut compartment in the gut bacterial communities of two Cerambycidae species (Coleoptera). J Microbiol 55, 21-30.

Klindworth, A., Pruesse, E., Schweer, T., Peplies, J., Quast, C., Horn, M. and Glöckner, F. 2012. Evaluation of general 16S ribosomal RNA gene PCR primers for classical and nextgeneration sequencing-based diversity studies. Nucleic Acids Res 41, e1-e1.

Lee, Z. M. P., Bussema III, C. and Schmidt, T. M. 2008. rrn DB: documenting the number of rRNA and tRNA genes in bacteria and archaea. Nucleic Acids Res 37, D489-D493.

Lozupone, C. and Knight, R. 2005. UniFrac: a new phylogenetic method for comparing microbial communities. Appl Environ Microbiol 71, 8228-8235.

Mateos, M., Castrezana, S. J., Nankivell, B. J., Estes, A. M., Markow, T. A. and Moran, N. A. 2006. Heritable endosymbionts of Drosophila. Genetics 174, 363-376.

McMurdie, P. J. and Holmes, S. 2013. phyloseq: An R package for reproducible interactive analysis and graphics of microbiome census data. PLoS ONE 8, e61217.

McMurdie, P. J. and Holmes, S. 2014. Waste not, want not: why rarefying microbiome data is inadmissible. PLoS Comput Biol 10, e1003531.

Mercier, C., Boyer, F., Bonin, A. and Coissac, E. 2013. SUMATRA and SUMACLUST: fast and exact comparison and clustering of sequences.

Mikaelyan, A., Dietrich, C., Köhler, T., Poulsen, M., Sillam-Dussès, D. and Brune, A. 2015. Diet is the primary determinant of bacterial community structure in the guts of higher termites. $\mathrm{Mol}$ Ecol 24, 5284-5295.

Montagna, M., Chouaia, B., Mazza, G., Prosdocimi, E. M., Crotti, E., Mereghetti, V., Vacchini, V., Giorgi, A., De Biase, A., Longo, S., Cervo, R., Lozzia, G. C., Alma, A., Bandi, C. and Daffonchio, D. 2015. Effects of the diet on the microbiota of the Red Palm Weevil (Coleoptera: Dryophthoridae). PLoS ONE 10, 1-22.

Montagna, M., Gómez-Zurita, J., Giorgi, A., Epis, S., Lozzia, G. and Bandi, C. 2014. 
Metamicrobiomics in herbivore beetles of the genus Cryptocephalus (Chrysomelidae): toward the understanding of ecological determinants in insect symbiosis. Insect Science 22, 340-352.

Oksanen, J., Blanchet, F. G., Friendly, M., Kindt, R., Legendre, P., McGlinn, D., Minchin, P. R., O'Hara, R. B., Simpson, G. L., Solymos, P., Stevens, H., Szoecs, E. and Wagner, E. 2017. vegan: Community Ecology Package.

Osimani, A., Milanović, V., Cardinali, F., Garofalo, C., Clementi, F., Pasquini, M., Riolo, P., Ruschioni, S., Isidoro, N., Loreto, N., Franciosi, E., Tuohy, K., Petruzzelli, A., Foglini, M., Gabucci, C., Tonucci, F. and Aquilanti, L. 2018. The bacterial biota of laboratory-reared edible mealworms (Tenebrio molitor L.): From feed to frass. Int J Food Microbiol 272, 49 - 60.

Pérez-Cobas, A. E., Maiques, E., Angelova, A., Carrasco, P., Moya, A. and Latorre, A. 2015. Diet shapes the gut microbiota of the omnivorous cockroach Blattella germanica. FEMS Microbiol Ecol 91, fiv022.

Priya, N. G., Ojha, A., Kajla, M. K., Raj, A. and Rajagopal, R. 2012. Host plant induced variation in gut bacteria of Helicoverpa armigera. PLoS ONE 7, 1-10.

Raymann, K. and Moran, N. A. 2018. The role of the gut microbiome in health and disease of adult honey bee workers. Curr Opin Insect Sci.

Schloss, P. D., Westcott, S. L., Ryabin, T., Hall, J. R., Hartmann, M., Hollister, E. B., Lesniewski, R. A., Oakley, B. B., Parks, D. H., Robinson, C. J. and others 2009. Introducing mothur: open-source, platform-independent, community-supported software for describing and comparing microbial communities. Appl Environ Microbiol 75, 7537-7541.

Shao, Y., Chen, B., Sun, C., Ishida, K., Hertweck, C. and Boland, W. 2017. Symbiont-derived antimicrobials contribute to the control of the lepidopteran gut microbiota. Cell Chem Biol 24, 6675.

Shetty, S. A., Hugenholtz, F., Lahti, L., Smidt, H. and de Vos, W. M. 2017. Intestinal microbiome landscaping: insight in community assemblage and implications for microbial modulation strategies. FEMS Microbiol Rev 41, 182-199.

Shi, W., Xie, S., Chen, X., Sun, S., Zhou, X., Liu, L., Gao, P., Kyrpides, N. C., No, E. and Yuan, J. S. 2013. Comparative genomic analysis of the endosymbionts of herbivorous insects reveals ecoenvironmental adaptations: biotechnology applications. PLoS Genet 9, 1-12.

Stamatakis, A. 2014. RAxML version 8: a tool for phylogenetic analysis and post-analysis of large phylogenies. Bioinformatics 30, 1312-1313.

Staubach, F., Baines, J. F., Künzel, S., Bik, E. M. and Petrov, D. A. 2013. Host species and environmental effects on bacterial communities associated with Drosophila in the laboratory and in the natural environment. PLOS ONE 8, e70749.

Staudacher, H., Kaltenpoth, M., Breeuwer, J. A. J., Menken, S. B. J., Heckel, D. G. and Groot, A. T. 2016. Variability of bacterial communities in the moth Heliothis virescens indicates transient association with the host. PLoS ONE 11, 1-21. 
bioRxiv preprint first posted online Sep. 21, 2018; doi: http://dx.doi.org/10.1101/423178. The copyright holder for this preprint

(which was not peer-reviewed) is the author/funder, who has granted bioRxiv a license to display the preprint in perpetuity.

All rights reserved. No reuse allowed without permission.

553 Takahashi, H., Saito, R., Miya, S., Tanaka, Y., Miyamura, N., Kuda, T. and Kimura, B. 2017.

554 Development of quantitative real-time PCR for detection and enumeration of Enterobacteriaceae.

555 Int J of Food Microbiol 246, 92 - 97.

556 R Core Team 2015. R: A Language and Environment for Statistical Computing.

557 Turnbaugh, P. J., Hamady, M., Yatsunenko, T., Cantarel, B. L., Duncan, A., Ley, R. E., Sogin,

558 M. L., Jones, W. J., Roe, B. A., Affourtit, J. P. and others 2009. A core gut microbiome in obese 559 and lean twins. Nature 457, 480.

560 Vacchini, V., Gonella, E., Crotti, E., Prosdocimi, E., Mazzetto, F., Chouaia, B., Callegari, M., 561 Mapelli, F., Mandrioli, M., Alma, A. and Daffonchio, D. 2017. Bacterial diversity shift 562 determined by different diets in the gut of the spotted wing fly Drosophila suzukii is primarily 563 reflected on acetic acid bacteria. Env Microbiol Rep 9, 91-103.

564 Vandeputte, D., Kathagen, G., D’hoe, K., Vieira-Silva, S., Valles-Colomer, M., Sabino, J., 565 Wang, J., Tito, R. Y., De Commer, L., Darzi, Y. and others 2017. Quantitative microbiome 566 profiling links gut community variation to microbial load. Nature 551.

567 Vasanthakumar, A., Handelsman, J. O., Schloss, P. D., Bauer, L. S. and Raffa, K. F. 2008. Gut 568 microbiota of an invasive subcortical beetle, Agrilus planipennis Fairmaire, across various life 569 stages. Environ Entomol 37, 1344-1353.

570 Wang, Q., Garrity, G. M., Tiedje, J. M. and Cole, J. R. 2007. Naive Bayesian classifier for rapid 571 assignment of rRNA sequences into the new bacterial taxonomy. Appl Environ Microbiol 73, 52615725267.

573 Wang, Y. and Rozen, D. E. 2017. Gut microbiota colonization and transmission in the burying 574 beetle Nicrophorus vespilloides throughout development. Appl Environ Microbiol 83, e03250-16.

575 Welte, C. U., de Graaf, R. M., van den Bosch, T. J. M., Op den Camp, H. J. M., van Dam, N. 576 M. and Jetten, M. S. M. 2016. Plasmids from the gut microbiome of cabbage root fly larvae 577 encode SaxA that catalyses the conversion of the plant toxin 2-phenylethyl isothiocyanate. Environ 578 Microbiol 18, 1379-1390. 
bioRxiv preprint first posted online Sep. 21, 2018; doi: http://dx.doi.org/10.1101/423178. The copyright holder for this preprint

(which was not peer-reviewed) is the author/funder, who has granted bioRxiv a license to display the preprint in perpetuity.

All rights reserved. No reuse allowed without permission.

\section{Tables}

Table 1: PERMANOVA analysis of the community composition of the insect microbiota based on different diversity indices, with the percentage of the variance explained by each variable and the p-value in brackets

\begin{tabular}{|lllll|}
\hline Variable & Jacc & BC & Uni & wUni \\
\hline A. & All insects & & & \\
Treatment & $0.13(1 \mathrm{e}-3)$ & $0.19(2 \mathrm{e}-3)$ & $0.03(0.07)$ & $0.18(1 \mathrm{e}-3)$ \\
B. & Soil-reared insects & & & \\
Site & $0.14(1 \mathrm{e}-3)$ & $0.08(2 \mathrm{e}-3)$ & $0.09(1 \mathrm{e}-3)$ & $0.07(6 \mathrm{e}-3)$ \\
Subsample & $0.17(1 \mathrm{e}-3)$ & $0.18(1 \mathrm{e}-3)$ & $0.14(3 \mathrm{e}-3)$ & $0.20(1 \mathrm{e}-3)$ \\
\hline
\end{tabular}

581 Jaccard distances (Jacc), Bray-Curtis distances (BC), Unifrac distances (Uni), weighted Unifrac distances (wUni).

582 A. Comparison of soil-reared insects and control insects. Models contain one explanatory variable: soil treatment. B.

583 Comparison of soil-reared insects. Models contained two explanatory variables: site and soil subsample 


\section{Figures Legends}

Figure 1: Experimental design A. Location of the two sampling sites. CDS: Causse-De-La-Selle (N4349.884' E00341.222'; CDS sample); MTF: Montferrier-sur-Lez (N4340.801' E00351.835'; MTF sample). B. At each sampling site, we obtained three soil subsamples at positions $10 \mathrm{~m}$ apart. C. Distribution of insects in soil subsamples. Each soil subsample was split into four portions, each of which was placed in a plastic box, in which it was mixed with sterilized wheat bran. Eight insects per soil subsample (two insects/box) were analyzed. Five insects placed in a box containing sterile wheat bran only were used as a control. D. Insects were placed, for five days, at $15^{\circ} \mathrm{C}$, in plastic boxes containing the soil subsamples mixed with sterile wheat bran. They were then starved by incubation for 24 hours in Petri dishes. The insects were then killed, their guts were dissected, and total DNA was extracted from each gut.

Figure 2: Alpha diversity of the gut microbiota A. Rarefaction curves. Each curve represents one insect. Control insects, insects reared in CDS soil samples and insects reared in MTF soil samples are shown in yellow, blue and red, respectively. B. Alpha diversity indices for the insect gut microbiota. CDS1-3 and MTF1-3 are the subsamples from the sampling sites (three for CDS and three for MTF). BRAN is the control treatment: insects reared on sterile wheat bran. (i) Chao1 extrapolated richness. Pairwise Wilcoxon rank-sum test, CDS-MTF: p-value = 2e-3, BRAN-CDS: p-value $=2 \mathrm{e}-3$, BRAN-MTF: $\mathrm{p}$-value $=0.01$ (ii) Shannon diversity index. Pairwise Wilcoxon ranksum test, CDS-MTF: $\mathrm{p}$-value $=1 \mathrm{e}-3$, BRAN-CDS: -value $=$ 5e-05, BRAN-MTF: $\mathrm{p}$-value $=8 \mathrm{e}-05$ C. Taxonomic assignment of OTUs to family level. Each bar represents an insect. Each subsample (i.e. CDS1-3 and MTF1-3) was divided into four portions, each of which was placed in a separate plastic box before the experiment. For each subsample, insects sharing the same letter (A, B, C or 
bioRxiv preprint first posted online Sep. 21, 2018; doi: http://dx.doi.org/10.1101/423178. The copyright holder for this preprint

(which was not peer-reviewed) is the author/funder, who has granted bioRxiv a license to display the preprint in perpetuity.

All rights reserved. No reuse allowed without permission.

D) were taken from the same plastic box. The 10 families with the largest relative abundances are shown in different colors, and the others are grouped together in the "Others" category.

Figure 3: PCOA analysis based on the four beta diversity distances. Each dot corresponds to one insect. The percentage of variance explained by each axis is indicated in brackets. Yellow, blue and red dots correspond to BRAN (control), CDS and MTF samples respectively. For CDS and MTF samples, dot shape represents the identity of the soil subsample, i. e. CDS1, CDS2 and CDS3, or MTF1, MTF2 and MTF3.

Figure 4: Assignment of shared OTUs according to the V3-V4 region of the $16 S$ rRNA gene A. Venn diagram of OTUs found in at least one insect from each treatment. B. Bar plot of the relative abundance of the 44 OTUs common to the three treatments (in gray) and the 59 OTUs found only in soil treatments (CDS and MTF) (red stripes). The taxonomic assignment of these OTUs is detailed in C. and D.. Insects from the various treatment were pooled for these bar plots: 5 insects for BRAN, 24 insects for CDS and 22 insects for MTF. The relative abundance of OTUs was calculated from the total number of reads for each insect pool. We show here taxonomic assignments to genus level or to the lowest taxonomic level, for which the bootstrap score was $<80 \%$. Some OTUs differ in sequence, but were assigned to the same taxonomic group. These sequences are differentiated by a number. On each graph, the 15 OTUs with the largest relative abundance are shown in color and the others are grouped together in the "Others" category. OTU names followed by a star $\left(^{*}\right)$ belong to the Enterobacteriaceae family.

Figure 5: Quantitative PCR on two taxa of the core microbiota A. Gene copy number (GCN) per $\mu \mathrm{L}$ of DNA extract for Pse-16S, a specific marker of the genus Pseudomonas. Pairwise Wilcoxon 
bioRxiv preprint first posted online Sep. 21, 2018; doi: http://dx.doi.org/10.1101/423178. The copyright holder for this preprint

(which was not peer-reviewed) is the author/funder, who has granted bioRxiv a license to display the preprint in perpetuity.

All rights reserved. No reuse allowed without permission.

rank sum test with Holm p-value adjustment, BRAN-CDS: p-value $=0.013$, BRAN-MTF: p-value $=0.013$, MTF-CDS: p-value $=0.18$. B. GCN per $\mu \mathrm{L}$ of DNA extract of Entero-rplP, a specific marker of the Enterobacteriaceae family. Samples from control (BRAN) had the maximum $\mathrm{Ct}$ value of 40, meaning that the initial Entero-rplP quantity was under the qPCR detection threshold, i.e. < 246 GCN. Pairwise Wilcoxon rank sum test with Holm p-value adjustment, BRAN-CDS: pvalue $=0.016$, BRAN-MTF: -value $=0.016$, MTF-CDS: $\mathrm{p}$-value $=0.31$. 
bioRxiv preprint first posted online Sep. 21, 2018; doi: http://dx.doi.org/10.1101/423178. The copyright holder for this preprint

(which was not peer-reviewed) is the author/funder, who has granted bioRxiv a license to display the preprint in perpetuity.

All rights reserved. No reuse allowed without permission.

\section{Additional Files}

\section{Additional file 1: Relative abundance and taxonomic assignment of OTUs}

594 Insects from the various treatments were pooled for these bar plots: 5 insects for BRAN, 24 insects

595 for CDS and 22 insects for MTF. The relative abundance of OTUs was calculated from the total

596 number of reads for each insect pool. We show here taxonomic assignments to genus level or to the

597 lowest taxonomic level for which the bootstrap score was $>80 \%$. Some OTUs differ in sequence

598 but were assigned to the same taxonomic group. These sequences are differentiated by a number.

599 On each graph, the 15 OTUs with the largest relative abundances are shown in color and the others

600 are grouped together in the "Others" category. OTU names followed by a star $\left(^{*}\right)$ belong to the

601 Enterobacteriaceae family.

\section{Additional file 2: Example of a microbiota pattern in PCR replicates}

603 We checked the reproducibility of PCR, by performing three technical PCR replicates (the three

604 bars of the chart) on a sample chosen at random, with the whole metabarcoding procedure

605 performed separately for each replicate. We show here the results for the CDS1D3 sample.

\section{Additional file 3: OBITools workflow for $16 \mathrm{~S}$ rRNA analysis}

RMD_OBITools_workflow_V3V4.pdf and

RMD_OBITools_workflow_gyrB.pdf

contain 
bioRxiv preprint first posted online Sep. 21, 2018; doi: http://dx.doi.org/10.1101/423178. The copyright holder for this preprint

(which was not peer-reviewed) is the author/funder, who has granted bioRxiv a license to display the preprint in perpetuity.

All rights reserved. No reuse allowed without permission.

\section{Additional file 4: Raw table of reads counts}

611 tab_div_V3V4.csv and tab_div_gyrB.csv contain raw abundance data and diversity indices for each

612 sample, as determined with the 16S rRNA and gyrB genes, respectively. Samples are shown in rows 613 and OTUs in columns.

\section{Additional file 5: OTU taxonomic assignment}

615 V3V4_assignment.txt is the assignment data for each 16S rRNA OTU obtained with RDPclassifier

616 and the RDPII database. gyrB_assignment.csv is the assignment data for each gyrB OTU obtained

617 with the MOTHUR classifier and the Barret et. al 2014 reference database.

\section{Additional file 6: Primers used for qPCR}

$619 \mathrm{PE}_{\text {standard }}$ corresponds to PCR efficiency on gDNA standard samples, $\mathrm{PE}_{\text {gut }}$ corresponds to PCR

620 efficiency on a pool of gut DNA from samples used for qPCR analysis.

\section{Additional file 7: Statistical analysis workflow}

622 RMD_R_workflow.pdf contains R scripts used to perform statistical analysis and to produce the

623 figures presented in this study.

\section{Additional file 8: R functions used in the statistical analysis workflow}

625 - src_routine_boostrap_threshold.R is an R function for extracting the lowest taxonomic level 626 according to a given bootstrap threshold from assignment files 
A.

B.

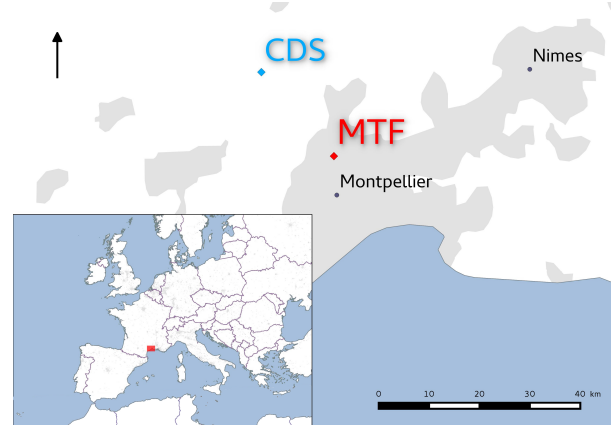

C.

Each soil subsample

(CDS1-3, MTF1-3)

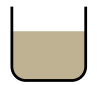

Control (BRAN): sterile wheat bran
CDS

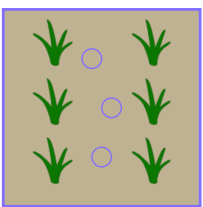

3 soil subsamples
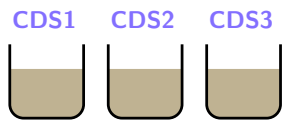

D.
MTF

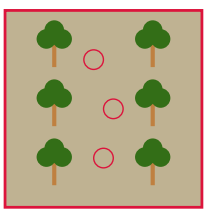

3 soil subsamples
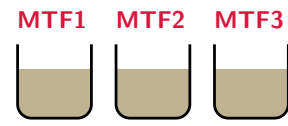

Box $A$ Box B Box $C$ Box $D$
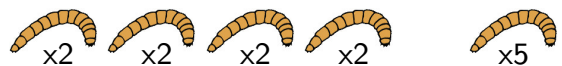

Box A-D

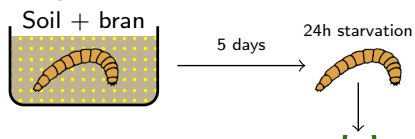

Gut dissection DNA extraction 
A.

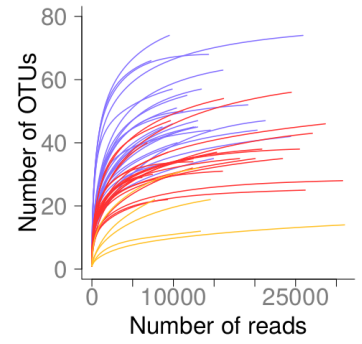

B. (i)

(ii)

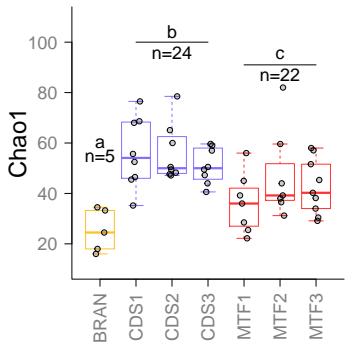

C.

$\square$ Enterobacteriaceae

- Pseudomonadaceae

$\square$ Moraxellaceae

Aeromonadaceae

$\square$ Streptococcaceae

$\square$ Carnobacteriaceae

- Enterobacteriales

- Comamonadaceae

$\square$ Xanthomonadaceae

$\square$ Enterococcaceae

$\square$ Others

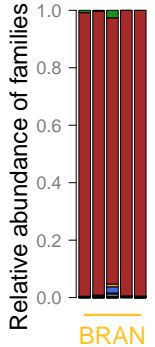

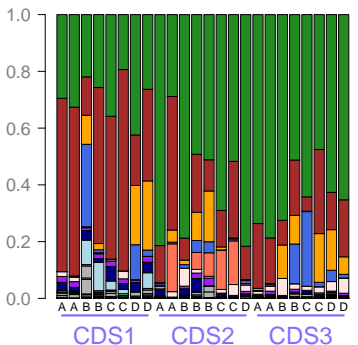

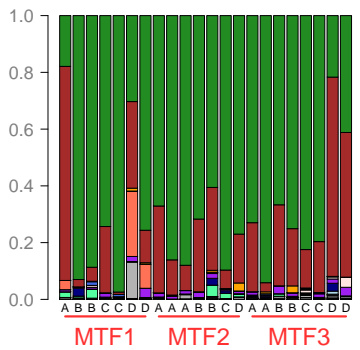


Jaccard

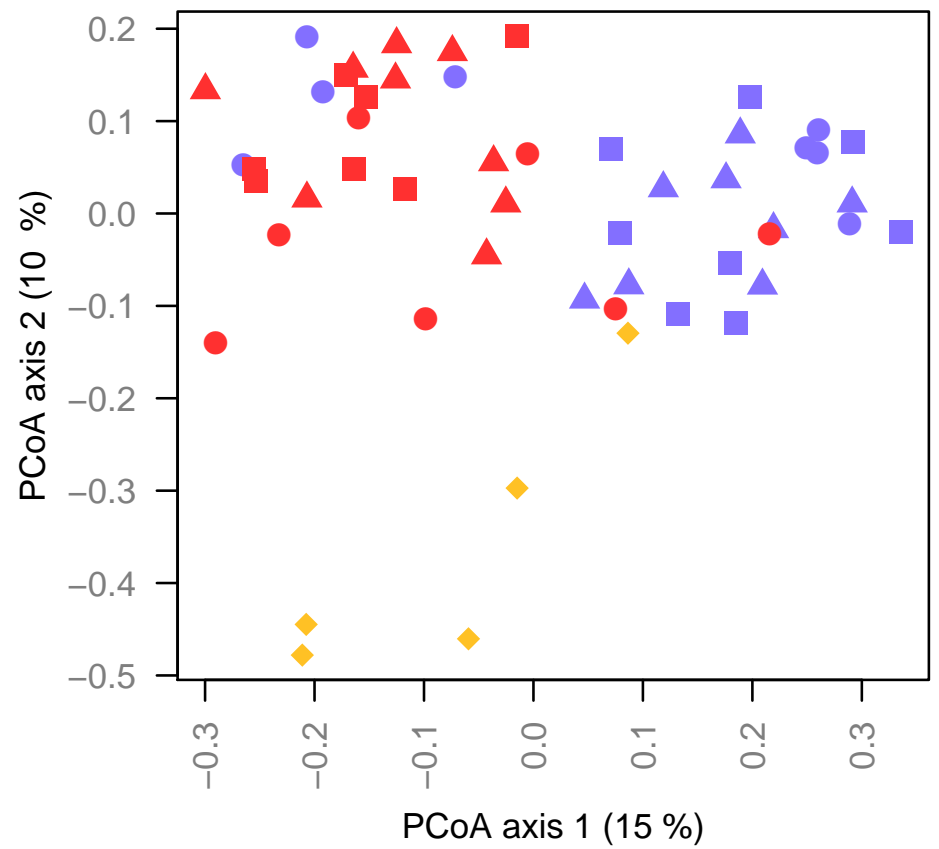

Unifrac

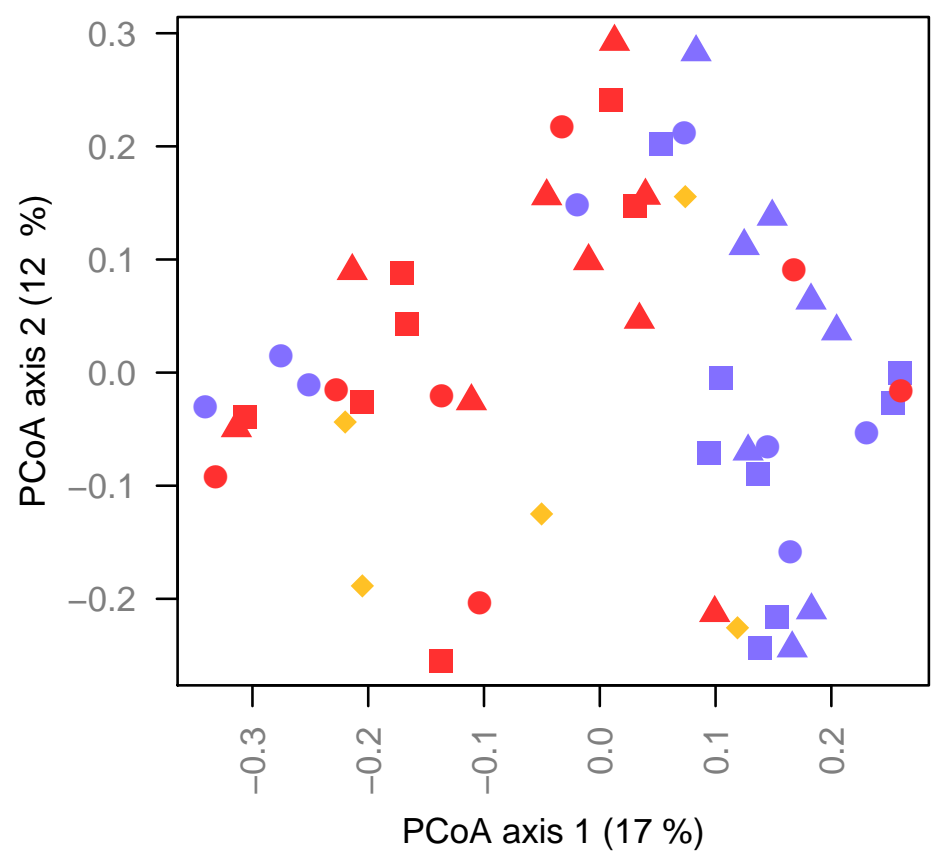

Bray-Curtis

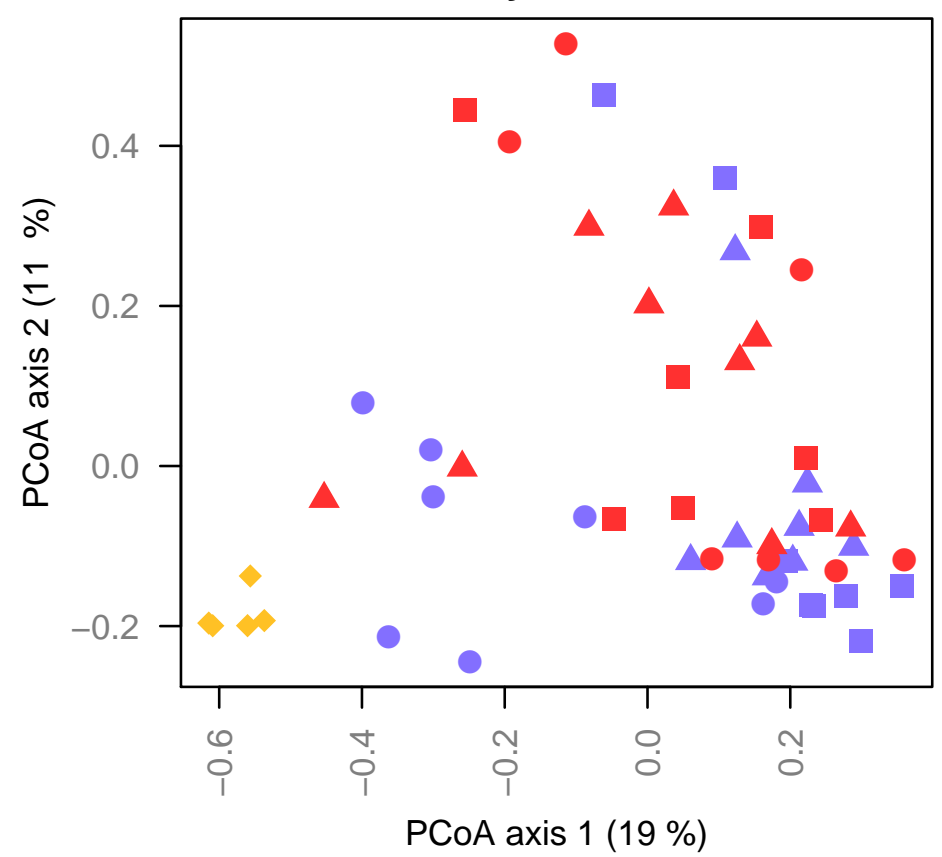

wUnifrac

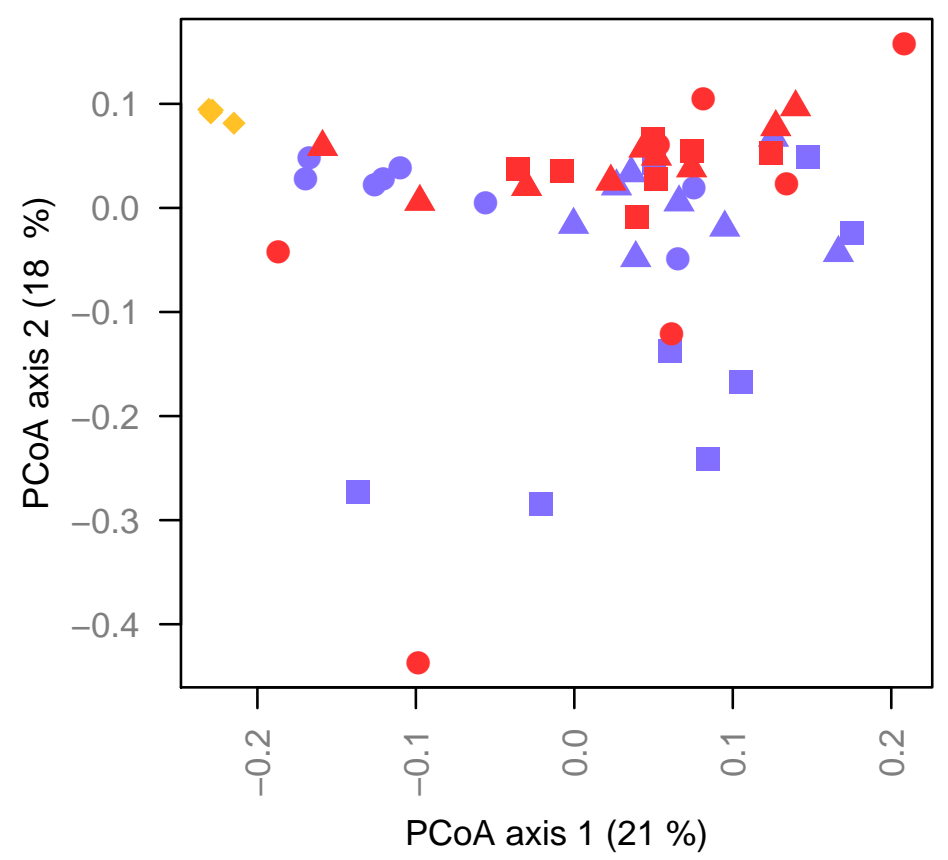

Treatment:

- BRAN

- CDS

- MTF

Subsample:

ㅁ 1

$\circ 2$

$\triangle 3$ 
A.

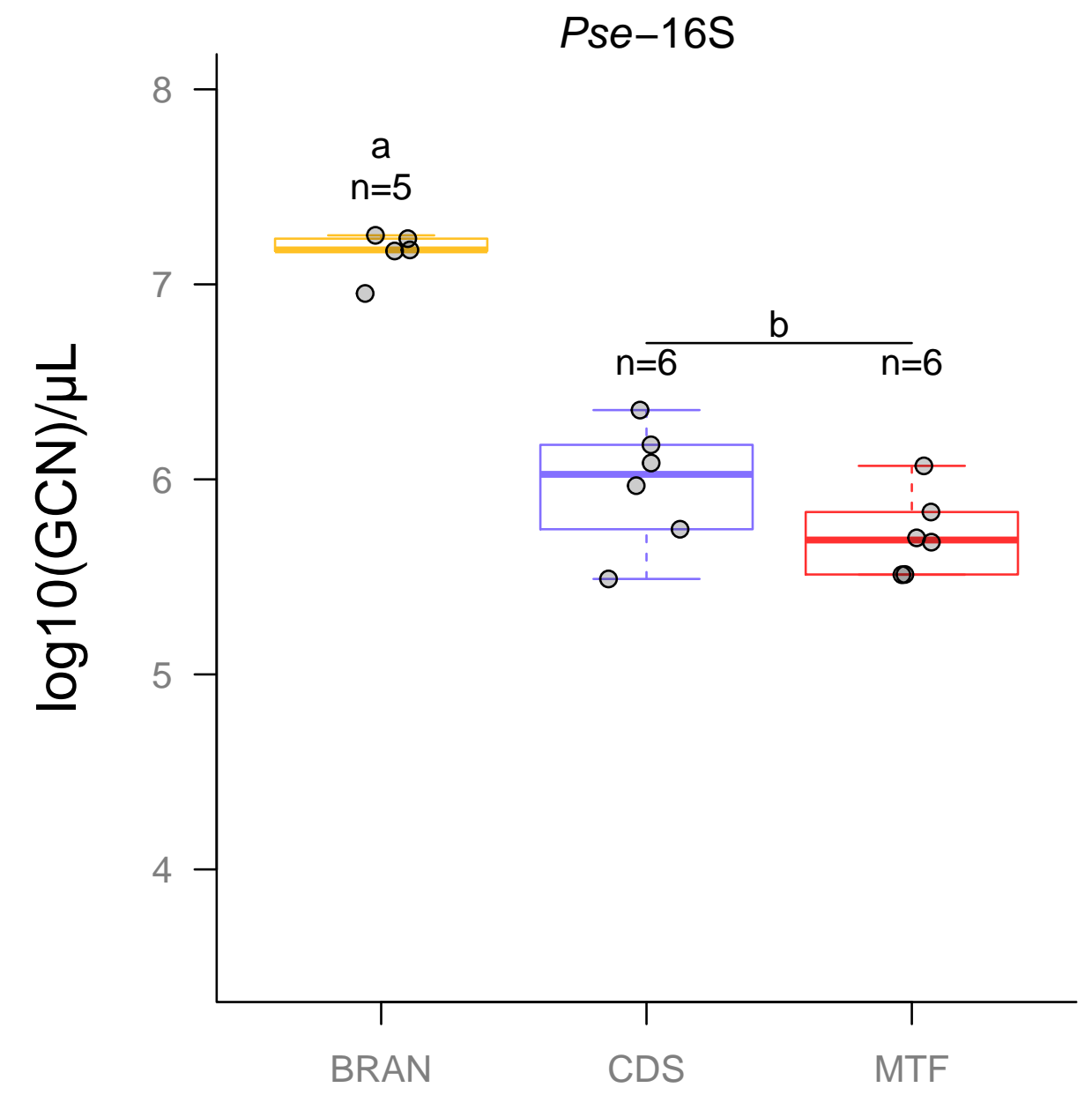

B.

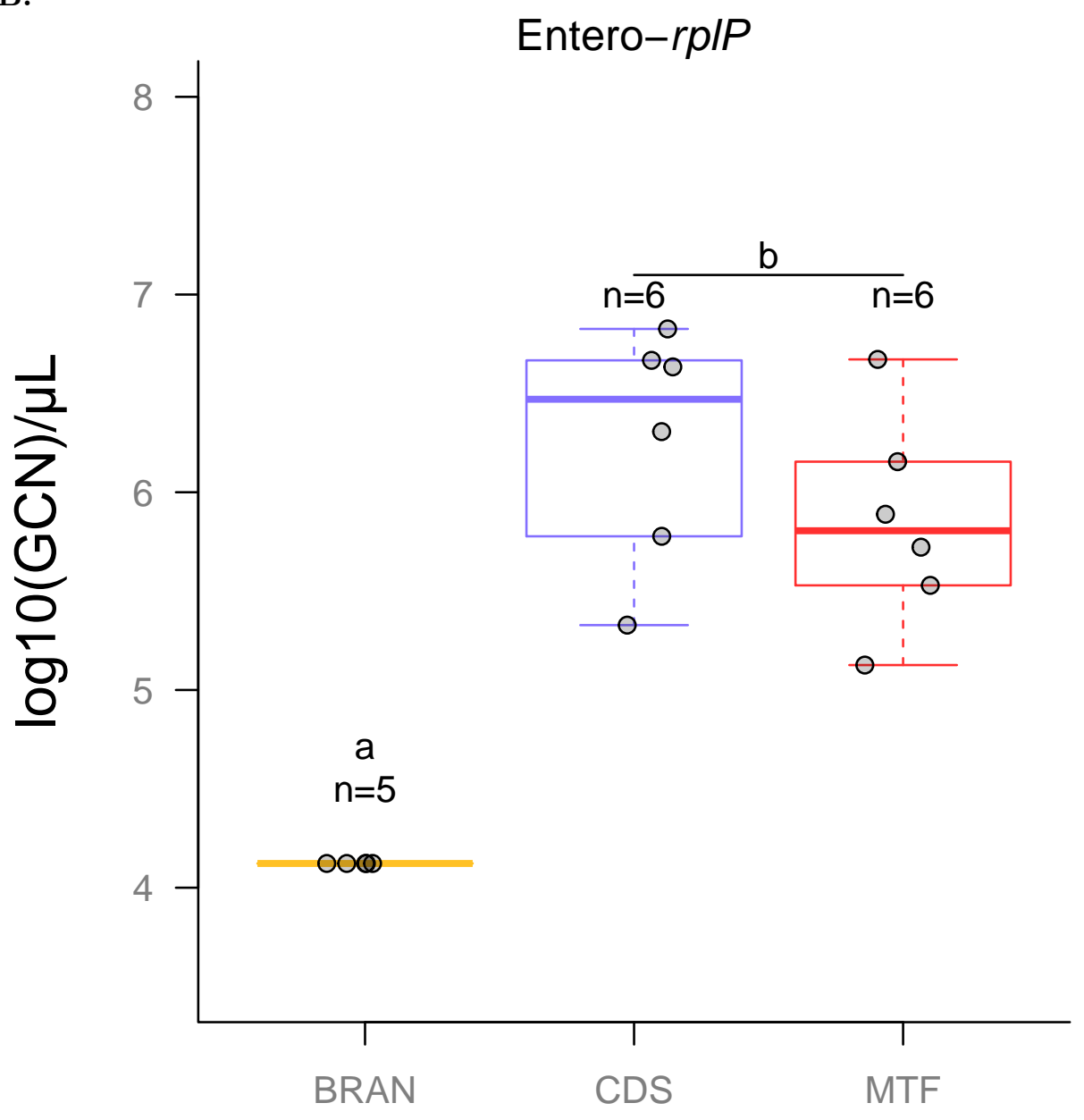

